\title{
KUVAJOURNALISMI TIEDON TUOTANTONA
}

Artikkelissa käsitellä̈n empiirisen aineiston avulla objektiivisen lehtikuvan paradoksia, jossa kuvien myönnetä̈n olevan ainajo-käsiteltyjä, mutta samalla puolustetaan niiden käsittelemättömyyttä ja autenttisuutta. Tuorein esimerkki tulee Reutersilta, joka irtisanoi kuvaajan elokuussa 2006 kuvankäsittelyn vuoksi ja julkaisi sen jälkeen tiukat kuvankäsittelyä koskevat objeet.

Artikkelissa sovelletaan Michel Foucault'n tematisointeja tiedon ja vallan välisistä subteista, ja kytketä̈n niitä ybteen journalistisiin käytäntöibin liittyvän tutkimusperinteen kanssa. Artikkelissa vastataan siihen, millä tavoin käsitys objektiivisuudesta rakentuu kuvajournalistisissa käytännöissä ja toiseksi, miten objektiivisuus voidaan ymmärtää tiedon tuotannoksi Foucault'n teoretisointien valossa.

Vuoden 2006 elokuun alkupuolella uutistoimisto Reuters ilmoitti, ettei enää tarvitse freelancekuvaaja Adnan Hajjin palveluksia. Hajj oli erehtynyt dramatisoimaan ottamaansa uutiskuvaa tavalla, joka ei sopinut hänen toimeksiantajansa kuvankäsittelystandardeihin. Itse käsittely ei ollut kovin dramaattinen. Kuvaaja oli monistanut kuvan savupilviä kuvankäsittelyohjelman avulla, vieläpä kohtuullisen kömpelösti. Otos oli kuitenkin poliittisesti kuumasta aiheesta, Israelin ilmavoimien tuhoamasta Beirutista.

Tapaus Hajj ei ole mitenkään ainutlaatuinen. Digitaalisen kuvankäsittelyn yleistyminen 1980-luvun lopulta lähtien on nostattanut jatkuvasti esiin kysymystä kuvajournalistisen esityksen uskottavuudesta (ks. esim. Lowrey 1998; Kobre 2004, 328-333; Seppänen 2005, 131). Lehtikuvan käsittelyn problematiikan nouseminen erityisen vahvasti esiin digitaalisen kuvankäsittelyn aikakaudella ei merkitse kuitenkaan sitä, että kuvia välttämättä muunneltaisiin aikaisempaa enemmän. Wilson Lowrey (1998) on osoittanut, kuinka suruttomasti lehtikuvia käsiteltiin modernin kuvajournalismin alkuaikoina 19201930-luvuilla. Myös tuolloin keskusteltiin - tosin hieman eri rekisterissä kuin nykyään - journalistisen kuvankäsittelyn rajoista ja myös mahdollisuuksista. Itse asiassa normi "käsittelemättömästä” lehtikuvasta nousi esiin hiljalleen vasta kuvajournalismin vakiintumisen myötä 1930-luvulta lähtien.

On selvää, että objektiivia, tarkennusta, rajausta ja kuvakulmaa vaihtamalla kuvaaja voi valita todellisuudesta juuri sellaiseen siivun, minkä haluaa ja mihin hänen ammattitaitonsa riittää. Salamalla voi nostaa esiin ja peittää. Kuvatoi- 
mittajat ja graafikot rakentavat kuville konteksteja, jotka vaikuttavat niiden merkityksiin joskus enemmän kuin rajuinkaan kuvankäsittely. Tästä huolimatta lehtikuvan objektiivisuus on ideaali, josta pidetään kiinni, ja joka aina silloin tällöin ponnahtaa näkyville kiistoina ja jopa kuvaajien potkuina. Lehtikuva elää siis paradoksissa ja kenties myös paradoksista: sen myönnetään olevan aina-jo-käsitelty, mutta samalla puolustetaan sen käsittelemättömyyttä ja lahjomattomuutta.

Paradoksi tekee ongelmasta kiehtovan ja samalla osoittaa sen, kuinka kiistoissa lehtivalokuvan objektiivisuudesta työstetään ainakin yhtä paljon valokuvan suhdetta journalistisiin käytäntöihin kuin sen suhdetta esittämäänsä todellisuuteen. Itse asiassa - Dona Schwartzin (1992) käsitettä käyttääksemme kyse on lehtikuvauksen objektiivisuuden koodien rakentumisesta journalistisissa käytännöissä ja koulutuksessa. Nämä koodistot ovat historiallisesti muuttuvia ja rakentuvat erilaisissa diskursiivisissa kentissä: debateissa kuvankäsittelyn rajoista, kuvajournalismin oppikirjoissa, ammattilaisten asenteissa ja keskusteluissa. Kuvankäsittelyn koodistot voidaan hyvin rinnastaa Gaye Tuchmanin (1972) jo 1970-luvun alussa esiin tuomiin uutistyön strategisiin rituaaleibin, toimintatapoihin, joihin nojautumalla journalistit voivat hyvällä omalla tunnolla todeta tekevänsä tosiasioihin pohjautuvaa journalismia.

Sekä Tuchmanin että Schwartzin ajatukset objektiivisuuden tuottamisesta nivoutuvat puolestaan Michel Foucault'n (esim. 1986, 131-132) ajatuksiin tiedon ja vallan välisistä suhteista. Foucault'laisesta näkökulmasta kuvajournalismia voidaan hyvin pitää yhtenä tiedon tuotannon alueena, jossa jatkuvasti työstetään - tiedostetusti tai tiedostamatta - kysymystä siitä, millainen on oikea kuva todellisuudesta. Tämän tiedon tuottamiseen sovelletaan erilaisia rituaaleja, koodistoja ja säännöstöjä: tuoreimpana esimerkkinä Reutersin hyvin yksityiskohtaiset ohjeet siitä, millä tavoin uutiskuvia saa käsitellä (ks. Schlesinger 2007). Valta näkyy näissä rituaaleissa muun muassa siinä, miten julkaisukelpoisen ja" hyvän" lehtikuvan rajat määrittyvät, mikä puolestaan vaikuttaa siihen, millä tavoin näkyvän ja näkymättömän raja (vrt. Foucalt 1980) julkisuudessa muotoutuu.

Kun kuvajournalisminkin objektiivisuutta työstetään journalismin arjessa, sen analysoiminen journalististen käytäntöjen tasolla on luonteva ratkaisu. Tällaista tutkimusta on kuitenkin tehty hyvin vähän. Wilson Lowrey $(2003 ; 1999$; 2002) on kartoittanut sitä, millä tavoin uutishuoneen eri ammattiryhmät suhtautuvat lehtikuvan digitaaliseen manipuloimiseen. Shiela Reaves (1992) on tutkinut aikakauslehtien ja sanomalehtien digitaalisen kuvankäsittelyn käytäntöjä. Edgar Huang (2001) on Reavesin menetelmää käyttäen tutkinut digitaalisen kuvankäsittelyn käytäntöjä lehden lukijoiden näkökulmasta. Suomessa kuvajournalistisia käytäntöjä ovat analysoineet muun muassa Kari Koljonen (2004) ja toinen tämän artikkelin kirjoittajista, Jenni Mäenpää (2006).

Tässä artikkelissa nostamme esiin yhtymäkohtia Foucault'n tiedon tuottamisen ja Tuchmanin objektiivisuuden rituaalien välillä ja sovitamme niitä yhteen empiirisen haastatteluaineiston kanssa (ks. Mäenpää 2006). Aineisto on osa laajempaa pro gradu -työssä analysoitua haastattelumateriaalia, joka sisältää maakuntalehden kuvajournalistiseen työprosessiin osallistuvien työntekijöiden näkemyksiä lehtikuvista ja toimitustyön käytännöistä. Artikkelia varten aineistosta on poimittu erikseen kaikki luonnehdinnat, jotka koskevat lehtikuvan objektiivisuutta. Näin tarkasteltavaksi valittua "objektiivisuuspuhetta" on ana- 
lysoitu teemoittelun ja kehysanalyysin (ks. esim. Väliverronen 1996; Karvonen 2000) avulla. Aineiston pohjalta muotoiltujen kolmen tulkintakehyksen avulla jäsennämme puhetta lehtikuvan objektiivisuudesta. Tältä pohjalta muodostetut keskeiset tutkimusongelmamme ovat seuraavat:

A. Millä tavoin käsitys objektiivisuudesta rakentuu kuvajournalistisissa käytännöissä?

B. Miten mainittu objektiivisuus voidaan ymmärtää tiedon tuotannoksi Michel Foucault'n teoretisointien valossa?

\section{TEOREETTISET LÄHTÖKOHDAT JA AINEISTO}

Teoreettisena lähtökohtanamme ovat Foucault'n käsitykset tiedon ja vallan suhteista. Hänen ajatuksiaan on käytetty aikaisemminkin valokuvan tutkimiseen (Sekula 1986; Tagg 1988; Tuori 2001). Sen sijaan kuvajournalismin analysoimiseen ranskalaisteoreetikkoa ei ole tiettävästi aikaisemmin sovellettu (poikkeuksena Seppänen 2005).

Foucault'n hahmotuksia vallasta on usein pidetty epäselvinä, koska hän ei suostu kovinkaan konkreettisesti kuvaamaan käsitteen merkityksiä, vaikka luonnehtiikin sitä monesta suunnasta (Foucault 1980, 155-290; 1982; 1986, 109-165; 1998, 70-72). Hänen valta-analyysinsä myös kytkeytyvät historialliseen tutkimukseen, jonka kohteina ovat muun muassa ihmistieteiden ja pakkolaitosten "arkeologia" ja "genealogia". Näistä syistä Foucault'n soveltaminen synkronisesti tämän päivän empiirisen tutkimuksen tarpeisiin ei ole lainkaan ongelmatonta (vrt. esim. Kendall \& Wickham 1999). Tähän problematiikkaan ei nyt ole mahdollista paneutua. Sen enempää emme puutu Foucault'n jälkeiseen valta-keskusteluun, joka on tietenkin avautunut tavattoman moneen suuntaan (ks. esim. Hindess 1996; Haugaard 1997). Sen sijaan käytämme foucault'laisia tematisointeja vallasta ja tulkitsemme niiden avulla aineistostamme esiin tulevia jäsennyksiä kuvajournalismin objektiivisuudesta.

Foucault'n kirjoituksista voidaan erottaa kolme vallan muotoa (Hélen 1994, 278-279, 284-290). Ensimmäistä voidaan kutsua repressiivis-ekslusiiviseksi vallaksi, joka perustuu fyysiseen väkivaltaan tai sillä uhkaamiseen. Tämä vallan muoto konkretisoituu despoottiin, hallitsijaan tai vaikkapa modernin valtion väkivaltakoneistoon. Toista vallan muotoa voidaan kutsua normatiivisesti integroivaksi vallaksi. Myös se perustuu pakkoon tai sillä uhkaamiseen, mutta kyseessä on hienovaraisempi tekniikka, jolla ihmisruumis ja mieli saadaan toimimaan tiettyjen normien mukaan. Konkreettinen esimerkki voisi olla vaikkapa erilaiset instituutiot, jotka kielloin ja rajoituksin saavat toimijoissa aikaiseksi tiettyjä vaikutuksiaः koulu, sairaala, armeija. Kolmas vallan muoto on nimeltään strategisesti integroiva valta, joka viittaa enemmän subjektiuden muotoutumiseen erilaisissa käytännöissä vuorovaikutuksessa toisten ihmisten ja sosiaalisten normien kanssa. Näkökulma on siis subjektissa, joka sosiaalistuu "vapaaehtoisesti" yhteiskunnan tai instituutioiden normeihin. Vallan muotojen erottelu on tietenkin analyyttinen ja eri muodot voivat lomittua toisiinsa.

Normatiivisen ja myös strategisesti integroivan vallan yksi keskeinen piirre on tiedon ja vallan kietoutuminen toisiinsa. Esimerkiksi psykiatrian ja lääketieteen käytännöissä patologiset tapaukset erotetaan normaaleista ennalta määritelty- 
jen kriteereiden perusteella. Tämä kriteeristö perustuu tieteenalan tuottamaan tietoon, joka tietomuotona auktorisoi tehdyt tulkinnat ja määrittelee toimijoiden diskursiivisia asemia. Tämä asemien muotoutuminen koskee siis yhtä lailla tiedon kohteita kuin sen tuottajiakin. Tietoa tuotetaan ja kierrätetään monissa muissakin instituutioissa, ja Foucault puhuu - viitaten ironiseen sävyyn klassiseen poliittiseen taloustieteeseen - totuuden "poliittisesta taloustieteestä" ja tiivistää"totuuden" (1986, 131-132) merkitykset viiteen piirteeseen:

- se painottuu tieteelliseen diskurssiin, instituutioihin ja käytäntöihin.

- siitä kamppaillaan ja kiistellään.

- sitä kulutetaan monin tavoin ja kierrätetään eri instituutioissa.

- sen tuotantoa kontrolloivat muutamat suuret poliittiset ja taloudelliset toimijat, kuten yliopisto, armeija, media.

- se on poliittisten debattien, vastakkainasettelujen ja ideologisten taistelujen tanner.

Määritelmistä on helppo huomata, että todeksi määritelty tieto on valuuttaa, joka muodostuu ja jota käytetään eri tavoin yhteiskunnan eri areenoilla. Voidaan siis sanoa, että iskulause "tieto on valtaa" korostaa yhtä, mutta vain yhtä tiedon ja vallan välistä suhdetta. Foucault'n katsannossa "totuus" ei viittaa millään yksiselitteisellä tavalla representaation ja todellisuuden väliseen suhteeseen, vaan representaation rakentumiseen "totuuden poliittisen talouden alueella". Oikeastaan parempi olisikin puhua niistä normeista ja ehdoista, joiden vallitessa legitiimi ja käyttökelpoinen tieto yhteiskunnassa tuotetaan. Tiedon tuotanto on nimenomaan normien ohjaamaa inhimillistä toimintaa: valta näkyy siinä, millaisin proseduurein tosi ja epätosi tai tietämisen arvoinen ja arvoton erotetaan toisistaan (Foucault 1986, 132). ${ }^{1}$

Foucault'n käsitys tiedon ja vallan suhteista voidaan rinnastaa Gaye Tuchmanin ajatuksiin journalismin objektiivisuudesta. Klassisessa artikkelissaan "Objectivity as Strategic Ritual" Tuchman (1972) raportoi - osallistuvaan havainnointiin perustuen - uutistyön rituaaleista, joiden avulla pidetään huolta siitä, että objektiivisuuden vaade täyttyy. Tällaisia ovat esimerkiksi suorien sitaattien ja uutisen kärkeä vahvistavan todistusaineiston käyttö, vastakkaisten näkökulmien esittäminen ja uutisen rakentaminen kertomukseksi, jossa tärkeät asiat ovat ensimmäisinä. Myös luotettavaksi havaittujen lähteiden käyttö ja uutisen vakiintuneet käsittelytavat auttavat ylläpitämään objektiivisuuden vaikutelmaa. Toisin sanoen tietyt rituaalit takaavat ja määrittelevät pätevän ja oikean tiedon ehtoja. Foucault’a ja Tuchmania yhdistää myös konstruktionistinen ote: kumpikaan ei ole varsinaisesti kiinnostunut siitä, onko tieto pätevää tai objektiivista, vaan siitä, millaisten proseduurien kautta tällainen vaikutelma kyetään legitimoimaan.

Objektiivisuuden rituaalit ovat tietenkin käytäntöjä, joihin subjektin täytyy jollain tavoin sopeutua. Tällöin objektiivisen journalismin strategiat ovat myös journalistin subjektiuden tuottamisen strategioita. Niissä subjektius nivoutuu yhteen tiedon tuotannon ja sitä määrittelevien rituaalien kanssa. Tämä on journalismissa toimivan vallan yksi keskeinen piirre.

Vallan ja objektiivisuuden rituaalien ohella artikkelimme painopiste liittyy luonnollisesti journalistien työkäytäntöjen tutkimukseen. Tällöin voidaan selvittää esimerkiksi sitä, millaiset asiat rajoittavat ammattilaisten työtä ja min- 
kälaisia intentioita he liittävät tuottamiinsa kuviin ja teksteihin. Ammattilaiset työskentelevät toisaalta rajoittavien ja vakiintuneiden historiallisten käytäntöjen varassa, toisaalta heillä on ainakin periaatteessa mahdollisuus vaikuttaa käsityksiimme esimerkiksi sukupuolirooleista. (Devereux 2003, 76-77.) Tuotannon tutkimuksessa voidaan erottaa erilaisia painotuksia sen perusteella, mille institutionaaliselle tasolle tutkimus keskittyy (Cottle 2003). Mikrotasolla kiinnostuksen kohteina ovat esimerkiksi työntekijöiden suhteet kollegoihin, teknologiaan ja ulkopuolisiin tahoihin, välitasolla organisaatiokulttuuri ja johtamisstrategiat ja makrotasolla lait ja sekä paikallinen että globaali teknologia- ja kilpailuilmapiiri.

Tämän artikkelin kannalta mielenkiintoisimman näkökulman avaa journalististen työkäytäntöjen mikrotason tutkimus, jota on eri muodoissaan tehty 1950luvulta lähtien. Valotusta ovat saaneet niin uutishuoneen sosiaalinen kontrolli (Breed 1997), työrutiinien ja byrokratian vaikutus juttujen kokoamiseen (Sigal 1999) ja odottamattomien uutistapahtumien sulautuminen osaksi toimituksellista rutiinia (Tuchman 1997). Uutistyön objektiivisuuden rituaalien ja myös tämän artikkelin kannalta keskeinen teoreettinen näkökulma nojautuu edellä mainittuun Tuchmanin klassikkotekstiin. Myös Timothy Gleasonin (1998) tutkimus kuvajournalismin muodoista on tulkinnoissamme tärkeällä sijalla.

Näistä teoreettisista asetelmista alun tutkimuskysymyksiin vastaaminen vaatii empiiristä paneutumista journalismin - tässä tapauksessa kuvajournalismin - toimituksellisten käytäntöjen tutkimiseen. Vallan toiminta kuvajournalistissa käytännöissä muotoutuu monin tavoin kuvajournalististen esitysten tuotantoon osallistuvien toiminnassa, puheissa ja sijoittumisessa tilaan toimituksellisen organisaation sisällä. Tässä yhteydessä ei ole mahdollista kartoittaa kuvajournalistisen prosessin toiminnan dynamiikkaa osallistuvan havainnoinnin avulla (vrt. Koljonen 2004). Sen sijaan keskeinen aineistomme muotoutuu toimijoiden haastatteluista.

Alkuperäinen aineisto kerättiin teemahaastattelumenetelmällä maakuntalehti Pohjalaisessa keväällä ja syksyllä 2005. Haastatteluihin osallistui yhteensä 14 lehden kuvajournalistiseen työhön osallistuvaa työntekijää. Aineistoa on aikaisemmin analysoitu pro gradu -työssä laadullisesti useiden eri teemojen kautta (Mäenpää 2006). Varsinainen aineisto muodostuu kaikista niistä lehtikuvan objektiivisuuden luonnehdinnoista, joita haastateltavat käyttivät alkuperäisessä aineistossa. Tätä artikkelia varten nämä luonnehdinnat on koottu omaksi aineistokseen, jonka laajuus on noin 20 liuskaa. Aineistosta olemme hahmottaneet keskeiset lehtikuvan objektiivisuuteen liittyvät tulkintakehykset. Kehysten yläotsikkona on objektiivisuus, jota kaikkien kehysten sisällä tarkastellaan eri näkökulmista. Kehykset ovat ammattilaisten puheen sisällä olevia diskursseja, joissa perustellaan ja määritellään hyvää kuvajournalismia.

Olemme erottaneet puheesta kolme diskurssia sen mukaan, mihin vetoamalla objektiivisuutta milloinkin perusteellaan. Nämä diskurssit tai kehykset, joille olemme antaneet nimet "kamera", "taide" ja "pimiösääntö", ovat kuvajournalistien kesken yleisesti jaettuja jäsennyksiä.

"Kamera" viittaa puheeseen, jossa pohditaan lehtivalokuvaa todellisuuden lahjomattomana kuvaajana viittaamalla - suoraan tai epäsuorasti - valokuvaan kamerakuvana. Toisin sanoen indeksisenä merkkinä, joka metonyymisesti edustaa kokonaisuutta. Kehys "taide" viittaa jäsennyksiin, jossa kuvajournalismin objektiivisuutta artikuloidaan suhteessa taiteeseen. "Pimiösääntö" puoles- 
taan viittaa analogisen ajan normeihin, joita kuvien käsittelemisessä noudatetaan digitaalisen kuvan aikakaudella. Kehykset tietenkin lomittuvat toisiinsa ja vaikuttavat siihen, millä tavoin ajatus kuvajournalismista tiedon tuotantona jäsentyy aineistossamme.

Seuraavaksi käymme läpi kunkin kehyksen hieman tarkemmin, tulkitsemme niitä edellä luonnehdittujen teoreettisten näkökulmien kautta ja pyrimme tulkinnoillamme vastaamaan tutkimusongelmiin.

\section{OBJEKTIIVISUUDEN KEHYKSET: KAMERA}

Foucault'n mukaan yksi keskeinen vallan piirre näkyy siinä, miten tosi ja epätosi erotetaan toisistaan. Kuvajournalismissa tämä erottelu tiivistyy objektiivisuuden ideaaliin ja sen diskursiiviseen työstämiseen, jossa kuvan edellytetään vastaavan todellisuutta. Tätä ideaalia aineistossa kuvattiin esimerkiksi seuraavien käsitteiden avulla: objektiivisuus, dokumentti, totuudellisuus, informaatio, pysäytetty hetki, tunnistettavuus, luonnollinen ja oikea tilanne.

Mä koitan pyrkiä informaation uutiskuvaan, ja sitä kuvaa ei muuteta silloin. Se on se, mikä se on sillä hetkellä, se viidessadas sekunnin osa sekunnista. Se pitää pysäyttää se hetki, eikä siihen sitten voi enää lisätä mitään tai ottaa pois. (Kuvaaja3)

Uutiskuva siis informoi lukijaa kertomalla yhdellä silmäyksellä, mitä on tapahtunut. Kuva on otettava oikealla hetkellä ja siinä pitää näkyä tapahtuman kannalta keskeiset ihmiset. Tällaisella hetkellisyydellä aineistossa viitataan usein ennakoimattomaan uutistapahtumaan, kuten onnettomuuksiin. Sitaatissa kaikuu myös reportaasikuvauksessa laajalle levinnyt ajatus "ratkaisevasta hetkestä". Sen mukaan kuvattavan todellisuuden elementit ovat vain lyhyen aikaa sellaisissa suhteissa toisiinsa, jotka tuovat esiin olennaiset merkitykset kuvattavasta aiheesta. Kuvaajan pitää olla valpas ja kyetä vangitsemaan tuo hetki. Ratkaisevaan hetkeen nojautumista voidaan pitää strategiana, jonka avulla kuvajournalismi perustelee objektiivisuuttaan.

Ratkaiseva hetki kytkeytyy kameran kulttuurisiin merkityksiin laitteena, jolla on kyky vangita ajallisesti erittäin lyhyt hetki todellisuudesta - tavallaan siis paljastaa jotain sellaista, mikä ylittää normaalin aistimellisuuden. Tämä kameran funktio aistien jatkeena liittyy luontevasti kuvajournalismin objektiivisuuden rituaaleihin, koska aistimellisuuden puutteiden paikkaaminen edesauttaa kykyämme tietää maailmasta tarkemmin ja samalla enemmän.

Kamera siis tallentaa siivun todellisuudesta, joka katsojan tai lukijan edessä alkaa edustaa todellisuutta. Samantyyppisiä rituaaleja löytyy uutistyöstä yleisemminkin, yhtenä esimerkkinä lainausmerkkien käyttö, jolloin sitaatti edustaa haastateltavan ajattelua kirjoitettua lainausta laajemmin (Tuchman 1972, 668669). Semioottisesti tarkasteltuna sekä suora lainaus haastateltavan puheesta että kuvan ottaminen ovat metonymioita. Vaikka kumpikin syntyy kuvaajan tai toimittajan valinnan tuloksena, ne antavat vaikutelman ikään kuin todellisuus itsessään puhuisi jutussa. Valokuvassa tämä efekti on oikeastaan voimakkaampi, koska kuvaaja on siinä vielä näkymättömämpi kuin tekstin kirjoittanut journalisti. 
Ratkaisevan hetken ohella kuvajournalismista löytyy muitakin strategioita objektiivisuuden ylläpitämiseksi. Dona Schwartzin (1992) tutkimissa kuvajournalismin oppikirjoissa kuvaajia johdatetaan objektiivisuuteen kertomalla, kuinka esimerkiksi laajakulmalinssillä kuvaan on mahdollista sisällyttää kaikki uutisen kannalta tärkeät elementit. Lisäksi yksinkertaisena pidetyn sommitelman ja kuvan tarkentamisen keskeisten toimijoiden kasvoihin on todettu lisäävän uskottavuutta tapahtuman autenttisuudesta. Tällaiset käytännöt ovat kuvaajien ammattitaitoon kuuluvaa piilevää, sisäänrakennettua tietoa, jolloin kuvaajat kokevat olevansa puhtaasti tilanteiden tallentajia.

Jokainen kokenut journalisti kuitenkin tietää, että kuvat ovat kaikessa objektiivisuudessaankin aina valintojen tulosta. Tämä paradoksi piirtyy aineistossa esiin selkeästi:

Siihen, että onks se todellinen, niin sehän on niinku, että jokainen kuva on aina jonkun tulkinta jostain. Et mä en osaa ajatella semmosta, et ois niinku täysin objektiivinen joku juttu, et aina siinä on niinku jonkun kautta jonkun silmillä katottuna joku juttu. (Kuvaaja2)

Mutta se on justiin se uutiskuvan vaatimus se totuus. Sitten on kuvituskuva, ja se on taas sitten eri asia. (Kuvaaja1)

No, tavallaan (kuvan on kerrottava totuus), mutta siinäkin on sitten mahdollisuus muunnella sitä niinkun ottamalla se jostain eri kulmasta kuin joku muu. (Toimittaja)

Kuvajournalismin sisään siis rakentuu jännite maailmaa objektiivisesti rekisteröivän kameran ja alati arvaamattoman inhimillisen toimijan, kuvaajan, välille. Tämä jännite on huomattavasti vanhempi kuin valokuvakamera ja löytyy jo camera obscuran historiallisista tehtävistä ja niihin kutoutuvista diskursiivisista jäsennyksistä. Esimerkiksi 1600-luvulla laitetta käytettiin sekä tarkkojen tieteellisten havaintojen tekoon että maagisten elämysten tuottamiseen, joilla huijattiin tavallista rahvasta (ks. Seppänen 2005). Sama binariteetti esiintyy myös 1900-luvulla niin valokuvaa koskevassa arkiajattelussa kuin valokuvatutkimuksen perinteessäkin. Teoreettisesti painavin ja samalla kaiketi tunnetuin esimerkki on André Bazin, joka kuuluisassa artikkelissaan "Valokuvan ontologia" (1945) kirjoittaa seuraavasti:

Valokuvauksen omaleimaisuus maalaustaiteeseen verrattuna on siis sen olemuksellisessa objektiivisuudessa. Niinpä linssiryhmää, joka muodostaa ihmissilmää korvaavan kamerasilmän, sanotaan 'objektiiviksi'. Ensimmäistä kertaa alkuperäisen esineen ja sen representaation välillä ei ole muuta kuin toinen esine. Ensimmäistä kertaa ulkomaailman kuva muodostuu automaattisesti ja ankaran determinismin mukaisesti ilman ihmisen luovaa väliintuloa. Valokuvaajan persoonallisuus ei puutu peliin muuta kuin ilmiön valinnan, orientoitumisen ja pedagogiikan myötä; niin silmiinpistävä kuin se onkin lopullisessa teoksessa, se ei ole mukana samassa mielessä kuin maalarin persoonallisuus. Kaikki taiteet perustu- 
vat ihmisen läsnäoloon; ainoastaan valokuvassa nautimme hänen poissaolostaan. Valokuva vaikuttaa meihin samalla tavoin kuin "luonnollinen" ilmiö, kuin kukka tai lumen kristallikide, joiden kauneutta ei voi erottaa niiden alkuperästä, kasvi- tai kivimaailmasta. (Bazin 1983, 182-183.)

Bazinin esille ottamaan luonnollisuuteen liittyy valokuvalle keskeinen indeksisyys. Indeksisyys voi semiotiikassa tarkoittaa monia eri asioita, mutta yleismerkityksessään se tarkoittaa sitä, että merkin ja sen edustaman asian välillä on jonkinlainen kausaalinen suhde (ks. esim. Nöth 1995, 107-114; Colapietro 1993, 118). Tällöin voidaan ajatella, että valokuva on indeksinen merkki hyvin materiaalisessa mielessä: valonsäteet piirtävät kohteen kuvan filmin tai kennon pinnalle. Myös nauhoitettu haastattelu on indeksinen, koska haastateltavan puhe tallentuu sähkömekaanisen ja kausaalisen prosessin kautta nauhalle tai tiedostoon. Äänitallenteille rakentuu samantyyppistä todistusvoimaa kuin valokuvalle. Samasta syystä kumpikin on erinomainen tekninen väline Tuchmanin kuvaamien uutishuoneen objektiivisuuden rituaalien käyttöön. Valokuvan indeksisyyden vuoksi se ruokkii erityisen hyvin vaikutelmaa läsnäolosta itse tapahtumapaikalla. Vaikka valokuvan kuvakulmat ja rajaus olisivatkin valittuja, se on eittämätön todiste siitä että "lehtemme on ollut paikalla". Tähän indeksisyyden mukanaan tuomaan läsnäolon vaikutelmaan kiinnittää huomiota myös Roland Barthes Valoisassa buoneessaan (1980, suom.1985) todetessaan, että "valokuvauksessa en voi koskaan kieltää, etteikö kohde olisi ollut paikalla" (Barthes 1985, 82).

Kamerakuvan laajemmat diskurssit tunkeutuvat siis kuvajournalismin alueelle ja osaltaan tukevat journalismin objektiivisuuden strategioita. Samalla ne asettavat kuvajournalistille imperatiivin: sinun on oltava uskollinen kameralle, sen objektiiviselle kuvalle ja näin journalismille itselleen. Niinpä vastuu kuvan objektiivisuudesta lankeaa kuitenkin aina viime kädessä kuvaajan henkilökohtaisen eettisen harkinnan varaan. Hän on siis yhtä aikaa lehtikuvan totuudellisuuden uhka ja sen takuumies. Bazinin maalailema tekijän poissaolo voi hyvinkin olla valokuvan filosofista ydintä, kun valokuvaa verrataan maalauksen. Kuvajournalismin kentällä tekijän läsnäolo on kuitenkin kiistämätön sekä valokuvan objektiivisuuden uhkana että sen takaajana.

Foucault'laisesta teoreettisesta näkökulmasta tällainen jännite on odotettu. Valta ei toimi koskaan täydellisesti vaan siihen kuuluu murtumia, paradokseja, vastarintaa. Normatiivisen ja integroivan vallan toimivuuden edellytys on subjekti, joka vapaaehtoisesti toimii käytännöissä. Juuri tämän vapauden "hintana” vallan rakenteisiin tulee epävakautta. Tämä näkyy myös silloin, kun tiedon ja vallan monimutkaiset suhteet rakentuvat kuvajournalistisissa käytännöissä. Yhtenä osoituksena tästä voi pitää juuri kuvajournalistisen representaation halkeamaa indeksiseksi ja lahjomattomaksi todellisuuden esittäjäksi ja samalla aikaa kuvaajan - ja myös muiden toimijoiden - armoilla olevaksi rakennetuksi esitykseksi. Kuvajournalismin toimivuuden ja sen objektiivisen luonteen kannalta tätä halkeamaa on jotenkin pyrittävä hallitsemaan diskursiivisesti. Tällöin diskursiiviseen rakenteeseen tulee tyypillinen kieltämisen strategia: tiedän, että kuvaaja vaikuttaa valinnoillaan kuvan objektiivisuuteen, mutta siitä huolimatta kuva on objektiivinen, onhan se valokuva. 


\section{OBJEKTIIVISUUDEN KEHYKSET: TAIDE}

Taidepuhe tulee aineistossa esiin yhteyksissä, joissa kuvajournalistit haluavat korostaa omaa ammatti-identiteettiään esimerkiksi erottautumalla toimittajista. Kuvaajien ajatellaan omaavan taiteen konventioista peräisin olevan kyvyn ajatella visuaalisesti ja tehdä kuvista esteettisiä ja mielenkiintoisia. Paradoksi syntyy, kun kuvajournalistit yrittävät luovia objektiivisen dokumentoinnin ja kameralla maalailemisen välimaastossa. "Liian" taiteellisesti kohdettaan lähestyvä kuvaaja uhmaa lehtikuvaa informaation välittäjänä:

Se minkä mä oon nyt huomannu tässä kehityksessä on se, että se on menny liikaa taiteellisuuteen. Se on se kaikki mikä tulee näistä Taideteollisista, valokuvataiteen näistä...On liikaa valokuva, siis taiteillaan liikaa. Semmosia näkökulmia, mitä ihminenkään ei tota.. Kuvataan semmosista asennoista, että sä et oo koskaan semmosessa asennossa. Ihminen pitää kuvata normaalisti suoraan samalta tasolta. (Kuvaaja 3)

Mitä muuta siihen taiteellisuuteen kuuluu sitten, kun mainitsit tän, että kuvakulmia vaihdellaan? (Haastattelija)

No, mä en tiedä, se on itsetehostamista. Siinä ajatellaan vaan itteä, että kuinka mä saan sen kuvan tehtyä hyväksi. Ettei ajatella sitä lehden tekoa ollenkaan. Tää on mun näkemys. (Kuvaaja 3)

Joo-o. Tai mä kysyn toisella tavalla, eli miten lehtikuva eroo siitä taidekuvasta? (Haastattelija)

Kyllä lehtikuva, se on uutiskuva eli sä pysäytät sillä hetkellä sen hetken, mikä sulla on edessä. Taidekuva on se, että sä kikkailet jostain alakulmasta, pikkasen silmää näkyy, oven raosta kuvaat tai jotain vastaavaa. Yritetään saada sitä taiteellisuutta, sä et informoi silloin lukijaa oikeestaan mitenkään. (Kuvaaja 3)

Jos kuva on liian taiteellinen, sen dokumentoiva ja todellisuutta esittävä funktio alkaa siis rapautua. Tämän lisäksi taiteellisuus liittyy sitaatissa koristeluun ja kikkailuun. Taidekuva viittaa myös eräänlaiseen kuvaajan sisäänpäin kääntymiseen, jossa tärkeäksi tulee vain hänen henkilökohtaiset pyrintönsä, ei niinkään yhteistyön tuloksena syntynyt journalistinen lopputulos. Kuvan taiteellisuudesta puhuminen, sen nimeäminen ja sääntöjen asettaminen on yksi rituaali, jolla kuvajournalistinen diskurssi määrittelee rajojaan. Tieto ja valta kytkeytyvät tässä toisiinsa strategiassa, jossa kuvan todenmukaisuutta rakennetaan diskursiivisesti vetämällä rajoja sen taiteellisuuden suuntaan. Tällainen puhetapa rakentaa kuvajournalistista esitystä tietomuotona suhteessa taidekuviin ja taiteen kenttään laajemminkin.

Kuvasta tulee liian taiteellinen silloin, kun sen kuvakulmat ovat poikkeavia tai siitä on yksinkertaisesti hieman vaikea hahmottaa mitä se esittää. Tällöin kuvaa saatetaan luonnehtia huvittuneen ironisesti. Taiteellisuus on attribuutti kaikille sellaisille kuville, jotka eivät avaudu tarpeeksi nopeasti: 
Ei mun mielestä taiteellisuus oo mikään este kuvan julkasulle. Et uutiskuvahan voi olla vaikka kuinka korkealentosta taidetta. Et ei se niinku rajota sitä millään tapaa, ja sit tota, no tää nyt on tällanen sisäpiirin vitsi, että heh nyt tuli taidekuva. Ja se tarkottaa sitä, että siit ei kukaan ymmärrä, et mikä sen sisältö on. Ne on niinku tän tyyppisiä kuvia, ei ne välttämättä oo ees mitään taidekuvia, niist ei vaan kukaan ymmärrä, et mitä niis on. Ne saattaa olla avustajien ottamia hyviä otoksia. Kukaan ei vaan tajua, ne ei mee niinku läpi. Meiän pitää ajatella myöskin lukijoita siinä vaiheessa, että miks me pannaan tämmönen kuva lehteen, kun ei se meille ittellekään meinaa oikein avautua. (Päällikkö 1 )

Sitaatissa taiteellisuus yhdistyy "itsetehostamiseen". Tällä puhuja viittaa siihen, että kuvaaja ei ota huomioon oikeaa kontekstia, toisin sanoen journalismia, vaan pyrkii toteuttamaan omia sisäisiä ideoitaan. Tällaisessa puheessa taiteellisuus ymmärretään kuvan piirteeksi, joka kumpuaa jostain kuvan tekijän sisäisistä mielenliikkeistä ja ei välttämättä kommunikoi kuvan vastaanottajan kanssa "informatiivisesti", kuten journalistisen kuvan odotetaan tekevän. Taiteellisuus on siis jotain ei-kommunikatiivista, vaikeaa ja sisäsyntyistä. Taiteellisuuteen liittyy myös kuvan koristeellisuus, joka ei kuulu kovan uutiskuvan ominaisuuksiin: "Kyllä silloin, kun ollaan oikein toden kanssa tekemisissä, niin ei sitä silloin paljon koristella" (toimittaja).

Uutisjournalismin yksi keskeinen objektiivisuusstrategia on mielipiteiden ja tosiasioiden erottaminen toisistaan (Tuchman 1972). Journalistisissa käytännöissä tämä toteutetaan usein siten, että jos toimittajalla on jotain sanottavaa, hän voi kirjoittaa omalla nimellään kommentit varsinaisen jutun viereen, kainaloksi. Tämä vahvistaa osaltaan vaikutelmaa, että varsinainen juttu on vapaa arvostuksista ja valinnoista. Kuvajournalismissa tämä sama strategia rakentuu hieman eri tavoin. Valokuva itsessään on denotatiivinen todellisuuden heijastuma, mutta kuvaaja voi tietenkin esittää sen avulla tulkinnan todellisuudesta. Puhe taiteellisuudesta lehtikuvissa kytkeytyy tähän kysymykseen tulkinnasta, joka tuo mukaan kuvaan erilaisia konnotaatioita.

Kuvajournalistisessa ammattidiskurssissa näkemys muotoutuu usein siten, että "hyvällä kuvaajalla" on toinen jalka visusti maassa niin, että hän tiedostaa roolinsa ammattimaisena silminnäkijänä. Samalla hän kuitenkin työskentelee subjektiivisella otteella, intohimolla ja taiteellisuudella, jossa on parhaimmillaan mukana selkeä näkökulma ja halu heittäytyä ja tehdä uhrauksia työn eteen. Kuvajournalistisessa prosessissa syntyy usein taidetta, ikään kuin sivutuotteena, ja juuri se tekee kuvista niin mukaansatempaavia. (Ks. Newton 2001, 50.)

\section{OBJEKTIIVISUUDEN KEHYKSET: PIMIÖSÄÄNTÖ}

Kuten alussa totesimme, yksi keskeinen lehtikuvan roolia sekä objektiivisena esityksenä että pätevän tiedon tuotantona määrittelevä diskurssi koskee digitaalista kuvankäsittelyä. Tästä muodostuu myös kolmas aineistomme kehys.

Aineistossa tulee usein esiin nyrkkisääntö, jonka mukaan digitaalisille kuville saa tehdä samat käsittelytoimenpiteet, jotka perinteisen kuvalaboratorion aika- 
nakin ovat olleet mahdollisia. Tätä kuvankäsittelyn periaatetta voi kutsua pimiösäännöksi (ks. Mäenpää 2006).

Ei mulle ainakaan oo annettu (ohjeita kuvankäsittelystä). Mut kyl sen nyt niinku, mä pidän ite ainakin niin, et mä saan käsitellä, mut en muokata. Et mä saan tehdä periattees semmosii juttuja, mitä mä voisin tehdä pimiössä helposti. Mut ei niinku niin, et mä ottaisin kuvasta poijes tai toisin siihen lisää jotain. Rajaamalla, säätämällä sävyjä ja tummenuksilla, nostamalla jotain esiin tai. Tietty kaikki roskat ja sellaset otetaan poies, mut ei niinku ruveta muuttaan sisältöä. (Kuvaaja 2)

Kun kuvaajat vetoavat pimiösääntöön, he tarkoittavat yleensä kuvalle tehtäviä perussäätöjä kuten rajaamista, roskien poistoa, sävyjen ja kirkkauden säätöä ja terävöitystä. Vaikka pimiötekniikalla pystytään ja pystyttiin tekemään kuvaan myös suuria muutoksia, kuten elementtien lisäämistä tai poistamista, niitä pidetään vain marginaalisesti käytettyinä mahdollisuuksina. Pimiössä kuvamanipulaatioiden tekeminen oli digitaaliseen kuvankäsittelyyn verrattuna hidasta ja työlästä, minkä lisäksi tehdyt muutokset olivat usein selvästi nähtävissä lopputuloksissa.

Kun digitaalinen kuvankäsittely yleistyi, sen ajateltiin raunioittavan valokuvalle perinteisesti langetetun roolin toden esittäjänä, ja samalla alettiin puhua jälkivalokuvallisesta ajasta (ks. esim. Mitchell 1992, 29-31). Pimiösääntö osoittaa, kuinka kuvankäsittelyn helpottuminen digitalisoitumisen myötä ei ainakaan kuvajournalismin alueella merkinnyt kuvan totuusvaatimusten raunioitumista. Pikemminkin kyse on siitä, että kuvan objektiivisuutta uhkaava teknologinen murros otetaan hallintaan sovittamalla se analogisen kuvan käsittelynormeihin. Samalla uusi teknologia sovitetaan aikaisempiin objektiivisuuden tuottamisen journalistisiin rituaaleihin. Foucault'laisen totuuden poliittisen talouden kannalta tämä tarkoittaa sitä, että uuden teknologian tulo kuvajournalismin kentälle itse asiassa sovittautuu vanhoihin normeihin. Tämä - jos mikä - on osoitus historiallisten jatkuvuuksien olemassaolosta, mistä kertovat myös uudet ilmaukset kuten "Photoshop on digikuvaajan pimiö". Myös alan teollisuus käyttää ilmaisua digitaalinen pimiö (digital dark room) tai "valohuone" (lightroom), kun tarkoitetaan valokuvan jälkikäsittelyä kuvankäsittelyohjelmassa.

Tiedon tuotanto kiteytyy pimiösääntöön siten, että kuvajournalistisen tiedon tuottamiseen liittyy tiettyjä ehtoja.

Itsellä pitää olla kuvaajan moraali sellanen, ettei esimerkiksi rinnakkaiskuvasta oteta mitään elementtejä ja siirretä siihen toiseen kuvaan. [...] Mun mielestä hyvä sääntö on se, mitä pimiössäkin pystytään sellasia perusasioita tekeen. (Kuvaaja)

Tiedon tuotanto nojaa vahvasti kuvaajan ammatilliseen etiikkaan puheessa, jossa vedotaan pimiösääntöön. Tällainen puhe puolestaan rakentaa kuvaajan subjektiutta, jolloin Foucault'n termein kyse on strategisesti integroivasta vallasta. Ammattiin sosiaalistuessaan kuvaaja asettautuu "vapaaehtoisesti" rooliinsa totuuden takaajana, jolloin vastuunkannosta tulee osa hänen ammatti- 
identiteettiään. Digitaalisen kuvankäsittelyn aikakaudella kuvan tuottajien eli kuvajournalistien vastuu on korostunut entisestään.

Tämän on nostanut esiin myös mediatutkija Arild Fetveit (1999, 799-800), joka on tositelevisiota käsittelevässä artikkelissaan pohtinut digitaalistumisen vaikutusta kuvallisten esitysten uskottavuuteen. Hänen mukaansa visuaalisten representaatioiden uskottavuus on alkanut nojata aiempaa enemmän teknologioiden sijasta ihmisiin ja instituutioihin ja näiden antamiin takuisiin kuvan totuudesta. Näin siksi, että digitaalisen kuvankäsittelyn mahdollisuudet ovat pimiötyöskentelyyn verrattuna paljon laajemmat. Digitaalinen kuvankäsittely on muun muassa horjuttanut maalauksen ja valokuvan suhdetta. Kun kuvaa katsomalla ei voida enää päätellä, missä määrin sitä on manipuloitu, vastuu totuuden takaamisesta on siirtynyt kuvan tuottajalle. (Ks. myös Kobre 2004, 330-331.) Niin ikään Liz Wellsin $(1997,25)$ mukaan uudet keskustelunavaukset valokuvan totuudellisuudesta ovat seurausta digitalisoituneesta kuvien tuotannosta. Esteettisellä ja teknisellä tavalla indeksisessä suhteessa todellisuuteen olevan valokuvan auktoriteetti koetaan uuden tekniikan takia jälleen uhatuksi.

\section{YHTEENVETO: KUVAJOURNALISMI TIEDON TUOTANTONA}

Foucault'n (1986) mukaan yksi keskeinen vallan toiminnan ulottuvuus on erottelun tekeminen toden ja epätoden välille. Sekä tiede että journalismi pyrkivät monin tavoin diskursiivisesti hallitsemaan tätä erottelua ja uusintamaan vallan mekanismeja omissa käytännöissään. Kun Adnan Hajj sai potkut manipuloituaan kuviaan, hän sai tuta konkreettisesti vallan toimivuuden.

Foucault'n näkökulmasta tällaiset vallan avoimet manifestaatiot eivät ehkä ole kaikkein mielenkiintoisimpia, vaikka ne osoittavatkin jotain toden ja epätoden rajan rakentumisen mekanismeista. Analyyttisesti haastavampia ovat vallan muodot, joissa toimijat vapaaehtoisesti sopeutuvat erilaisiin sääntöihin, normeihin ja käytäntöihin. Ne ovat edellä kuvatun normatiivisen ja strategisesti integroivan vallan ydinalueella, jossa tieto ja valta kietoutuvat toisiinsa monin tavoin.

Olemme edellä analysoineet kuvajournalistien puhetta kolmen kehyksen kautta: kameran, taiteen ja pimiösäännön. Kukin kehys valottaa omalla tavallaan sitä, millä tavoin käsitys valokuvan objektiivisuudesta rakentuu kuvajournalistissa käytännöissä. Kukin kehys myös kuvastaa sitä, millä tavoin kuvajournalistit tuottavat puhetapoja, joissa rakennetaan rajaa toden ja epätoden välille ja samalla osallistutaan valtaprosessiin, joka määrittelee kuvajournalismin institutionaalista roolia todenmukaisen kuvan tuottajana ja samalla kuvajournalistien identiteettiä. Kun ammattilaiset määrittelevät hyvää kuvajournalismia ja puolustavat objektiivista valokuvaa puheessaan ja myös osin tiedostamatta omaksuttujen rituaalien avulla, he tuottavat ammatillista tietoa. Valta puolestaan määrittelee kuvajournalistisen tiedon tuottamisen normeja eli muodostaa reunaehdot sille, millaisia toimintamahdollisuuksia subjektilla on. Haastateltavien perustelut esimerkiksi ratkaisevan hetken vangitsemisen tärkeydestä tai kuvankäsittelylle asetetuista tiukoista reunaehdoista ovat osa tiedon tuotantoa, johon kuvajournalistit ovat ammatillisen asemansa perusteella valtaistettuja.

Kameraan sekä mekaanisena laitteena että kulttuurisena apparaattina kyt- 
keytyvät merkitykset luovat valokuvalle kuvajournalismin kontekstissa vahvan roolin todellisuuden kuvaajana. Valokuvan indeksisyys on osoitus ainakin kameran läsnäolosta tapahtumapaikalla, mikä on yksi uutistyön keskeinen rituaali. Tästä syystä myös teknisesti kehnoilla valokuvilla on poikkeuksellinen käyttöarvo journalismin kentällä: huonokin kuva on merkki paikallaolosta. Kamerakuvaan liittyy myös ratkaisevan hetken filosofia, sillä vain kameralla on mahdollista pysäyttää todellisuudesta siivu, joka mahdollisimman objektiivisesti edustaa sitä, mitä todella on tapahtunut. Sekunnin murto-osan kestävän tilanteen tallentaminen laajentaa näköaistin toimintaa kahdessakin mielessä. Se ylittää näköaistin fysiologiset rajat, koska silmä ei kykene näkemään kovin nopeita tapahtumia. Toisaalta se vie tallennetun tapahtuman ajallisesti ja tilallisesti uusiin ulottuvuuksiin. Kuvan välityksellä tapahtuma laajenee kaikkien katsottavaksi, niin kauan kuin kuva on muodossa tai toisessa olemassa.

Tuchmanilaisessa mielessä valokuvan metonyymisyys vastaa sitaattien käyttöä uutistekstissä. Indeksisyydestä valokuvalle rakentuu erityisen vahva rooli juuri visuaalisen todellisuuden "metonyymisenä sitaattina”. Tätä valokuvan roolia todellisuuden kuvaajana problematisoivat kuitenkin sekä valokuvan osittainen kiinnittyminen taiteen diskurssiin että digitaalisen kuvankäsittelyn mahdollistama entistä helpompi kuvan muokkaaminen.

Suomessa valokuvaajia on koulutettu pitkään taideoppilaitoksissa, ja valokuva on varsinkin 1960-luvulta lähtien noussut laajasti gallerioihin ja taiteen kentälle. Valokuvan rooli taidekuvana kytkee sen kulttuurisiin jäsennyksiin, joissa todellisuuden objektiivinen kuvaaminen ei ole erityisen vahvassa asemassa. Elämyksellisyys ja esteettinen kokemus ovat pitkälle korvanneet todellisuuden objektiivisen kuvaamisen. Tätä taidekuvan kulttuurisesta paikasta johtuvaa epävakautta yritetään kuvajournalistissa käytännöissä hallita monin tavoin. Aineistossamme tämä näkyy muun muassa siinä, että kuvien dekoratiivisuuteen ja kuvaajan taiteelliseen "itsetehostukseen" suhtaudutaan kielteisesti, usein ironian sävyttämänä. Toisaalta taiteen diskurssille ollaan jossain määrin valmiita antamaan periksi. Lehtikuvaaja ei ole taiteilija, mutta häneltä edellytetään tiettyä esteettistä silmää ja kykyä luovuuteen.

Kuvankäsittelyn digitalisoituminen on myös vaikuttanut valokuvan objektiivisuuden problematiikan kasvuun, koska digitaalisuus tarjoaa aiempaa paremmat välineet kuvien muokkaamiseen. Digitaalisuus nostattaa koko ajan keskustelua kuvajournalismin luotettavuudesta, ja monet suuret mediatalot ovat laatineen hyvinkin yksityiskohtaiset säännöt kuvien muokkaamiselle. Yksi tällainen on Reuters (ks. Schlesinger 2007). Tätä digitalisoitumisen kuvan objektiivisuudelle asettamaa uhkaa pyritään aineistossamme hallitsemaan pimiösäännön avulla. Journalistiselle kuvalle saa digitaalisesti tehdä sen, minkä on voinut analogisen kuvan aikana tehdä pimiössä. Tämä strategia osoittaa selvästi, kuinka digitaalisen aikakauden valokuvaa pyritään ainakin journalismin kontekstissa hahmottamaan analogiselta aikakaudelta periytyvien jäsennysten avulla. Samalla korostetaan kuvaajan etiikkaa ja henkilökohtaista vastuuta. Foucault'laisittain katsottuna pimiösääntö on yksi strategia, jolla valokuvan totuusfunktiota ylläpidetään ja mahdollistetaan toden ja epätoden erottaminen toisistaan (ks. Foucault 1986).

Valokuvan roolia journalismissa merkityksellistää sekin, että tiedon ja näkemisen väliset suhteet ovat länsimaisessa kulttuurissa olleet hyvin likeiset (ks. esim. Jenks 1995). Empiirisen luonnontieteen kehittymisestä lähtien näkemi- 
nen on ollut yksi keskeinen keino sekä tieteellisen tiedon hankkimiseen että sen testaamiseen. Myös humanistisissa ja yhteiskuntatieteissä havainnointi nojautuu vahvasti näköaistiin. Visuaalisena teknologiana valokuva siis kytkeytyy tieteeseen, joka Foucault'n $(1986,131-132)$ mukaan on keskeinen "totuuden poliittisen talouden" alue. Tästä näkökulmasta tulee myös osittain ymmärrettäväksi se kiihkeys, jolla kuvamanipulaatioon journalismissa suhtaudutaan. Manipuloimalla ei pelkästään rikota journalismin normia - tuchmanilaista objektiivisuuden rituaalia - vaan myös paljon syvemmälle ulottuva näkemisen ja tiedon historiallinen yhteys.

\section{Viitteet}

1 Tässä yhteydessä on tehtävä ero yleisempään, filosofiseen tiedon määritelmään, jossa korostetaan niin ikään tiedon ja totuuden yhteyttä. Klassinen tiedon käsite juontaa juurensa antiikin Kreikkaan ja Platoniin: tieto on hyvin perusteltu, tosi uskomus. Tiedolta edellytetään siis perusteluita ja totuutta, että se erottuisi luulosta tai arvauksesta. Totuuden problemaattisuuden takia tiedoksi päätyvät käytännössä kuitenkin useimmiten havainnot, jotka tukevat riittävän hyvin esitettyä väitettä. Myöhemmin tiedon käsitettä on edelleen lavennettu, ja filosofisessa käsiteanalyysissä määritellään tiedon eri lajeja. Niissä erottuvat karkeasti ei-kielellinen tieto kuten taito ja osaaminen sekä propositionaalinen, väitelausein perusteltavissa oleva tieto ja vielä laajemmin ymmärrettynä myös tietämys ja viisaus. (Ks. esim. Niiniluoto 1990, 48-66.) Foucault'n yhteydessä emme kuitenkaan puhu tiedosta tässä perinteisessä, filosofisessa mielessä.

\section{Kirjallisuus}

Barthes, Roland (1985) Valoisa huone. Suom. Martti Lintunen, Esa Sironen ja Leevi Lehto. Helsinki: Suomen valokuvataiteen museo \& Kansankulttuuri.

Bazin, André (1983/1945) Valokuvan ontologia. Suom. Leena Kirstina. Teoksessa Lintunen, Martti (toim.): Kuvista sanoin. Helsinki: Suomen valokuvataiteen museon säätiö, 178-186.

Breed, Warren (1997) Social Control in the Newsrooms: A Functional Analysis. Teoksessa Berkowitz, Dan (toim.) Social Meanings of News - A Text-Reader. London: Sage.107-122.

Colapietro, Vicent M. (1993) Glossary of Semiotics. New York: Paragon House.

Cottle, Simon (toim.) (2003) Media Organization and Production. London: Sage.

Devereux, Eoin (2003) Understanding the Media. London: Sage.

Fetveit, Arild (1999) Reality TV in the digital era: a paradox in visual culture? Media, culture and society, vol. 21, 787-804. London: Sage.

Foucault, Michel (1980) Tarkkailla ja rangaista. Suomentanut Eevi Nivanka. Helsinki: Otava.

Foucault, Michel (1982) The Subject and Power. Teoksessa Hubert L. Dreyfus \& Paul Rabibow: Michel Foucault: Beyond Structuralism and Hermeneutics. Sussex: Harvester Press, 208-226.

Foucault, Michel (1986) Power/Knowledge. Selected interviews and other writings 1972-1977. Edited by Colin Gordon. Sussex: Harvester Press.

Foucault, Michel (1998) Seksuaalisuuden historia. Suom. Kaisa Sivenius. Helsinki: Gaudeamus.

Gleason, Timothy Roy (1998) The Develoment of standard and alternative forms of photojournalism. Central Michigan university.

Haugaard, Mark (1997) The Constitution of Power: A Theoretical Analysis of Power, Knowledge and Structure.

Helén, Ilpo (1994) Michel Foucault'n valta-analytiikka. Kirjassa Risto Heiskala (toim.): Sosiologisen teorian nykysuuntauksia. Helsinki: Gaudeamus, 270-315.

Hindess, Barry (1996) From Hobbes to Foucault. Osxford: Blackwell.

Huang, Edgar Shaohua (2001) Readers' Perception of Digital Alteration in Photojournalism. Journalism \& communication monographs, 3:3, 147-182, Association for Education in Journalism \& Mass Communication.

Jenks, Chris (toim.) (1995) Visual Culture. London: Routledge. 
Karvonen, Erkki (2000) Tulkintakehys (frame) ja kehystäminen. Tiedotustutkimus 23:2, 78-84.

Kendall, Gavin \& Gary Wickham (1999) Using Foucault's Methods. London: Sage.

Kobre, Kenneth (2004) Photojournalism. The Professionals' Approach. 5th Edition. Amsterdam: Focal Press.

Koljonen, Kari (2004) Juputusta, pönötystä ja lehtikuvia. Satakunnan Kansan kuvajournalismin arvot ja käytännöt. Teoksessa Kari Koljonen, Tiina Rajamäki \& Janne Seppänen. Valtakadun verkoissa. Toimitustyön organisointi ja kuvajournalistinen työprosessi Satakunnan Kansassa. Tutkimusraportti. Journalismin tutkimusyksikkö, tiedotusopin laitos. Tampere: Tampereen yliopisto, 36-74.

Lowrey, Wilson (1998) Altered Plates: Photo Manipulation and the Search for News Value in the Early and Late Twentieth Century. Paper presented to the Visual Communication Division, AEJMC National Convention. August 1998, Baltimore, Maryland.

Lowrey, Wilson (1999) Routine news: the power of the organization in visual journalism.

News Photographer, 54:4.

Lowrey, Wilson (2002) Word people vs. picture people: normative differences and strategies for control over work among newsroom subgroups. Mass Communication \& Society, 5:4, 411-432.

Lowrey, Wilson (2003) Normative conflict in the newsroom: the case of digital photo manipulation. Journal of Mass Media Ethics, 18:2, 123-142.

Mitchell, William J. (1992) The Reconfigured Eye: Visual Truth in the Post-Photographic Era. Cambridge: MIT-Press.

Mäenpää, Jenni (2006) Kuvan tekijät. Kuvajournalistiset käytännöt ja työprosessi sanomalehti Pohjalaisessa. Pro gradu. Tiedotusopin laitos, Tampereen yliopisto.

Newton, Julianne H. (2001) The burden of visual truth. The role of photojournalism in mediating reality. Mahwah, New Jersey: Lawrence Erlbaum Associates.

Niiniluoto, Ilkka (1990) Informaatio, tieto ja yhteiskunta. Filosofinen käsiteanalyysi. Helsinki: Valtion painatuskeskus.

Nöth, Winfried (1995) Handbook of Semiotics. Bloomington \& Indianapolis: Indiana University Press.

Reaves, Shiela (1992) What's Wrong with this Picture? Newspaper Research Journal

1992, 13/14, 4/1, 131-155.

Sekula, Allan (1986) The Body and the Archive. October nro 39 (Winter 1986), 3-64.

Schlesinger, David (2007) The use of Photoshop. Report on Reuters actions after publishing altered photographs. Uutistoimisto Reutersin päätoimittajan blogi osoitteessa: http://blogs.reuters.com/2007/01/18/the-use-of-photoshop/ (Luettu 30.8.2007)

Schwartz, Dona (1992) To tell the truth: Codes of objectivity in photojournalism. University of Minnesota: Gordon and Breach science publishers.

Seppänen, Janne (2005) Visuaalinen kulttuuri. Teoriaa ja metodeja mediakuvan tutkijalle. Tampere: Vastapaino.

Sigal, Leon (1999) Reporters and Officials: The Organization and Politics of Newsmaking. Teoksessa Tumber, Howard (toim.) News: A Reader. Oxford: Oxford University Press. 224-234

Tagg, John (1988) The Burden of Representation. Essays on Photographies and Histories.

Tuchman, Gaye (1972) Objectivity as strategic ritual: An examination of newsmen's notions objectivity. American journal of Sociology, 77/4 (1972), 660-79.

Tuori, Santeri (2001) Vallan kuva. Valokuva kontrollipolitiikan välineenä. Helsinki: Musta Taide.

Väliverronen, Esa (1996) Ympäristöuhkan anatomia. Tiede, mediat ja metsän sairaskertomus. Tampere: Vastapaino.

Wells, Liz (toim.) (1997) Photography. A critical introduction. London: Routledge.

Zelizer, Barbie (1995) Words against Images. Positioning Newswork in the Age of Photography. Teoksessa Hardt, Hanno \& Brennen, Bonnie (eds.): Newsworkers. Toward a History of the Rank and File. London \& Minneapolis: University of Minnesota Press, 135-159. 